\title{
Antitumour Activities of Selected Pure Compounds Identified from the Serum of Crocodylus porosus, Malayopython reticulatus, Varanus salvator and Cuora kamaroma amboinensis
}

\author{
Shareni Jeyamogan ${ }^{1}$, Naveed Ahmed Khan ${ }^{2 *}$, Ruqaiyyah Siddiqui ${ }^{3}$
}

\begin{abstract}
Objectives: Here we determined antitumour effects of purified compounds such as Valdecoxib, Rofecoxib, L-Methionine and Artocarpin against cancer cell lines. Methods: Using purified compounds, assays were performed to determine their effects against cancer cell lines using growth inhibition assays, cytotoxicity assays, and cell survival assays against HeLa, PC3 and MCF7 cells. Results: The results showed that the selected small molecules L-Methionine, Rofecoxib, and Artocarpin suppressed the growth of more than $90 \%$ PC3 cells at $40 \mu \mathrm{M}$. Similarly, Valdecoxib alone and in combination with other molecules exhibited potent growth inhibition and cytotoxicity against cancer cells tested. Peptide from the serum of M. reticulatus, demonstrated selective cytotoxicity against cancer cells without inhibiting the growth of normal cells. Conclusion: These findings are significant and provide a basis for the rational development of therapeutic anticancer agents, however intensive research is needed to determine in vivo effects of the identified molecules together with their mode of action to realize these expectations.
\end{abstract}

Keywords: Cancer- anticancer molecules- cytotoxicity- growth inhibition- HeLa- PC3- MCF7

Asian Pac J Cancer Prev, 22, Anticancer Activity of Natural Compounds: HOW's on Methods and Reports Suppl, 97-106

\section{Introduction}

In spite of the advances in treatment modalities and supportive care, significant rise in cancer morbidity and mortality highlights the need for the discovery of new effective anticancer agents (Bray et al., 2018; Ferlay et al., 2015; Parkin et al., 2001; Siegel et al., 2020). Natural products containing bioactive extracts remain an important source for the development of novel therapeutic drug. To date, various anticancer bioactive molecules from natural products for instance, plants, animals and microorganisms had led to the development of a few good commercialized anticancer drugs (Ehrhardt et al., 2013; Kang et al., 2011; Kampan et al., 2015; Ma and Wang, 2009).

The search for potential anticancer molecules from the animal Kingdom largely remains an untapped source. For instance, reptiles such as crocodiles, snakes and water monitor lizards, thrive in contaminated and polluted environments exposing them to toxic and carcinogenic heavy metal elements such as selenium, cadmium, mercury, arsenic, chromium, nickel, cobalt and zinc (Lehner et al., 2013; Tellez and Merchant, 2015; Xu et al., 2006). Moreover, these animals feed on germ-infested animals (Jeyamogan et al., 2017; Siddiqui et al., 2017), tolerate extreme levels of radiation
(Chandna et al., 2004) and have successfully survived the catastrophic Cretaceous-Paleogene mass extinction event (Jeyamogan et al., 2017; Siddiqui et al., 2017). Even with all of the above, these animals have prolonged lifespan with minimal cancer incidence reported (Sykes and Trupkiewicz, 2006). These findings suggests that animals living in polluted environment, yet have prolonged lifespan, are a potential source of anticancer molecules. In support, our recent studies demonstrated anticancer potential of serum of the salt water crocodile Crocodylus porosus, snake Malayopython reticulatus, Asian water monitor lizard Varanus salvator and tortoise Cuora kamaroma amboinensis (Jeyamogan et al., 2019). Using LC-MS, we identified several hundred molecules. Next, for the identification of potential Anticancer Peptides candidates, the Machine Learning Based Prediction of Anticancer Peptides (MLACP) methodology was used that employs the SVM (SVMACP) and Random Forest (RFACP) method to calculate the probability of a peptide in being a potential anticancer peptide using a combinations of features from the peptide sequence, amino acid composition (AAC), dipeptide composition (DPC), Atomic composition (ATC) and physicochemical properties (PCP). These findings led to the identification of numerous molecules with anticancer potential

${ }^{1}$ Department of Biological Sciences, School of Science and Technology, Sunway University, Bandar Sunway, Malaysia. ${ }^{2}$ Department of Basic Medical Sciences, College of Medicine, University of Sharjah, United Arab Emirates. ${ }^{3}$ College of Arts and Sciences, American University of Sharjah, University City, Sharjah, United Arab Emirates. *For Correspondence: naveed5438@gmail.com 
from the serum of the salt water crocodile Crocodylus porosus, snake Malayopython reticulatus, Asian water monitor lizard Varanus salvator and tortoise Cuora kamaroma amboinensis (Jeyamogan et al., 2019). Based on our earlier work, the overall aim of this study was to determine the anticancer efficacy of selected peptides and small molecules including (i) TFFPETWLWLLK, (ii) MDPPLLWR, (iii) WAFPLK, (iv) AFWLLLALHR, (v) LVVPVVVPALFSK, (vi) Valdecoxib, (vii) Rofecoxib, (viii) Artocarpin, and (ix) L-Methionine were investigated independently and in combination against several cancer cell lines. The discovery of antitumour molecules/peptides from these reptiles can pave the way for the discovery and development of therapeutic interventions. Overall, several compounds showed promising antitumour activities against cancer cell lines tested.

\section{Materials and Methods}

\section{Chemicals and reagents}

The chemicals and reagents used for the assays comprise of Lactate Dehydrogenase Cytotoxicity (LDH) kit (Roche Diagnostics, Indianapolis, USA), Trypan Blue (Merck Millipore, Germany), Roswell Park Memorial Institute 1640, L-Glutamine solution, Fetal Bovine Serum and Trypsin 2.5\% solution (Serana, Pessin, Germany), Penicillin Streptomycin antibiotic solution (Life Technologies, USA), Minimum Essential Medium Non-Essential Amino Acid (MEM NEAA) solution (Sigma Aldrich, United Kingdom), Ultra-pure deionized MiLi-Q water (EMD Milipore, Burlington, USA), Rofecoxib [4-(4'-methylsulfonylphenyl)-3phenyl-2-(5H)-furanone] (MedChem Express, Sweden), Artocarpin (Chemfaces, China), L-Methionine (Nacalai Tesque, Japan), Valdecoxib (Tokyo Chemical Industry Co., Japan), peptide A (TFFPETWLWLLK), peptide B (MDPPLLWR), peptide C (WAFPLK), peptide D (AFWLLLALHR) and peptide E (LVVPVVVPALFSK) (Genescript, USA) unless stated otherwise. Chemical analysis of peptides (HRMS) is shown in supplementary file. U2529EG150-13 contains HRMS for peptide sequence: LVVPVVVPALFSK; U2529EG150-10 contains HRMS for peptide sequence: AFWLLLALHR; U2529EG150-7 contains HRMS for peptide sequence: WAFPLK; U2529EG150-4 contains HRMS for peptide sequence: MDPPLLWR; U2529EG150-1 contains HRMS for peptide sequence: TFFPETWLWLLK.

For the identification of potential Anticancer Peptides candidates, the Machine Learning Based Prediction of Anticancer Peptides (MLACP) methodology (http://www. thegleelab.org/DHSpred.html) was used that employs the SVM (SVMACP) and Random Forest (RFACP) method to calculate the probability of a peptide in being a potential anticancer peptide. The calculation was done based on combinations of features from the peptide sequence, amino acid composition (AAC), dipeptide composition (DPC), Atomic composition (ATC) and physicochemical properties (PCP). All peptides were dissolved in distilled water. For Valdecoxib, ethanol was used as a solvent; for L-methionine, distilled water was used as a solvent; for Rofecoxib, DMSO was used as a solvent; and for
Artocarpin, DMSO was used as a solvent.

\section{Culture of cell lines}

Human cervical adenocarcinoma cells (HeLa) (ATCC ${ }^{\circledR C C L-2}{ }^{\mathrm{TM}}$ ), human breast adenocarcinoma cells (MCF7) (ATCC®HTB-22 ${ }^{\mathrm{TM}}$ ) and human prostate adenocarcinoma cells (PC3) (ATCC $® C R L-1435^{\mathrm{TM}}$ ) were purchased from American Type Cell Culture (ATCC). Human keratinocyte skin cells (Hacat) (CVCL_0038, CLS:300493) were procured from Cell Lines Service (CLS), Germany. Briefly, cells were cultured in Roswell Park Memorial Institute-1640 (RPMI-1640) supplemented with $10 \%(\mathrm{v} / \mathrm{v})$ foetal bovine serum (FBS), 1\% minimal essential media non-essential amino acid (MEM NEAA), $1 \%$ L-glutamine and $1 \%$ of antibiotic mixture comprising 10,000 Units/ml of penicillin and 10,000 $\mu \mathrm{g} /$ $\mathrm{ml}$ streptomycin. The cells were incubated in an incubator at $37^{\circ} \mathrm{C}$ with $95 \%$ humidity, with the supply of $5 \%$ carbon dioxide $\left(\mathrm{CO}_{2}\right)$ (Siddiqui et al., 2017).

\section{Growth inhibition assay}

Growth inhibition assay was carried out to investigate the cancer cell growth inhibition ability of small molecules and peptide sequences. Briefly, $3 \times 10^{4}$ cells were cultured onto 96 -well plates and incubated in a $95 \%$ humidified incubator at $37^{\circ} \mathrm{C}$ with the supply of $5 \% \mathrm{CO}_{2}$ until an approximately $50 \%$ semi-confluent monolayer of cells was achieved. Next, media were removed and cells were incubated with different concentrations of small molecules $(30 \mu \mathrm{M}-120 \mu \mathrm{M})$ and peptides $(24 \mu \mathrm{M}-120 \mu \mathrm{M})$ for $24 \mathrm{~h}$ (Table 4). An initial cell count was performed on the control well to calculate the number of viable cells present in the monolayer of the $50 \%$ semi-confluent well. Once a $100 \%$ confluent monolayer of cells were achieved in the control well, the media was discarded and the cells were trypsinized by incubation with $2.5 \mathrm{~g} / 1$ trypsin solution for $5 \mathrm{~min}$ at $37^{\circ} \mathrm{C}$. Next, fresh media containing $10 \%(\mathrm{v} / \mathrm{v})$ FBS was added to stop the activity of trypsin and cells were subjected to centrifugation at 3,000xg for $5 \mathrm{~min}$. Supernatant was then discarded and the cell pellet was re-suspended in fresh media and viable cells were enumerated using Trypan blue exclusion assay. The membrane of cells incubated with the different concentrations of small molecules $(30 \mu \mathrm{M}-120 \mu \mathrm{M})$ and peptides $(24 \mu \mathrm{M}-120 \mu \mathrm{M})$, if damaged, enabled penetration of Trypan blue dye. Thus, these damaged and non-viable cells were stained blue. In contrast, intact membrane of viable cells prevented the penetration of Trypan blue dye, resulting in unstained cells. The percentage of cell growth was calculated by comparing the number of viable cells present in treated wells and control wells. The growth inhibition was calculated in this manner: Total cells per $\mathrm{ml}=$ Total cells counted $\mathrm{x}$ [dilution factor/number of counted squares] x 10,000 cells per ml. All experiments were conducted at least twice, in duplicate and the results are presented as mean \pm standard error.

\section{Cell cytotoxicity assay}

Cell cytotoxicity assay was carried out to investigate the cytotoxic activity of small molecules and peptide sequences against cancer cells. Briefly, $4 \times 10^{5}$ cells were 
cultivated in 96-well plates until a confluent monolayer is achieved. Next, media was discarded and replaced and cells were incubated with different concentrations of small molecules $(30 \mu \mathrm{M}-120 \mu \mathrm{M})$ and peptides $(24 \mu \mathrm{M}-120 \mu \mathrm{M})$ for $24 \mathrm{~h}$ (Table 4 ) for $24 \mathrm{~h}$ at $37^{\circ} \mathrm{C}$ in a $5 \% \mathrm{CO}_{2}$ incubator. The negative control wells were treated with media alone, Cisplatin (positive control), Ampicillin (negative control) and DMSO/Ethanol/Distilled water (solvent control). The supernatant from each well were collected and the percentage of cytotoxicity/cell death was determined via Lactate Dehydrogenase (LDH) cytotoxicity kit (Siddiqui et al., 2017) after $24 \mathrm{~h}$. LDH, is a soluble enzyme which is present in the cytoplasm of viable cells. Cells with affected and damaged membranes results in the release of LDH enzymes from the cytoplasm to the surrounding matrix. The LDH enzymes from the supernatant, activates the conversion of lactate to pyruvate, resulting in the generation of $\mathrm{NADH}$ and $\mathrm{H}+$. Following that, the $\mathrm{H}$ and $\mathrm{H}+$ from $\mathrm{NADH}$ and $\mathrm{H}+$ is transferred to the tetrazolium salt p-iodo-nitrotetrazolium violet (INT) (solution in the kit) by the diaphorase enzyme (from the kit), resulting in the reduction of this colourless salt to the red formazan dye. The absorbance of each well was then read at 490nm using a microplate reader. The positive control well which represents total cell death was prepared by incubating the cells with $0.1 \%$ Triton X-100 for $60 \mathrm{~min}$ at $37^{\circ} \mathrm{C}$. The percentage cell death was calculated using the given formula: (test absorbance value - negative control absorbance value/total LDH release absorbance value - negative control value x $100=\%$ cytotoxicity). All experiments were conducted at least twice, in duplicate and the results are demonstrated as mean \pm standard error.

\section{Cell survival assay}

Cell survival assay was done to investigate the revival potential of cancer cells treated with different concentrations of small molecules and peptides for 24 h (Table 4). Briefly, cells were grown in 96 well plates until a $100 \%$ confluency was achieved. Next, media was removed and the cells were incubated with different concentrations of small molecules $(30 \mu \mathrm{M}-120 \mu \mathrm{M})$ and peptides $(24 \mu \mathrm{M}-120 \mu \mathrm{M})$ for $24 \mathrm{~h}$ (Table 4$)$. Cells were incubated with media alone and Ampicillin for the negative control wells, Cisplatin for the positive control wells and DMSO, Ethanol and Distilled water for the solvent control wells. Next, the supernatant was removed and the cells were detached using $2.5 \mathrm{~g} / 1$ trypsin for $5 \mathrm{~min}$. Media comprising 10\% (v/v) FBS was then added to stop trypsin activity and the cell suspension was subjected to centrifugation at 3,000xg for $5 \mathrm{~min}$. Fresh media was then added to resuspend the cell pellet, and the cells were re-grown in new 96 well plates. After $24 \mathrm{~h}$, the number of cells were enumerated to determine cell growth. All experiments were conducted at least twice, in duplicates.

\section{Statistical analysis}

The data are representative of the mean \pm standard error of several independent experiments. Statistical significance for differences was evaluated using a 2-sample t-test; two-tailed distribution, contrasting the mean of two different experiments repeated using similar conditions. P values were determined for analysis.

\section{Results}

Valdecoxib selectively inhibited more than $40 \%$ growth of MCF7 cancer cells without affecting normal cells

The growth inhibition effects of different concentrations of small molecules $(30 \mu \mathrm{M}-120 \mu \mathrm{M})$ and peptides $(24 \mu \mathrm{M}-120 \mu \mathrm{M})$ as a single drug or in combination, against cancer cells namely, human cervical adenocarcinoma cells (HeLa), human breast adenocarcinoma cells (MCF-7), prostate adenocarcinoma cells (PC3), as well as normal human skin keratinized cells (Hacat) were determined via the growth inhibition assay. Interestingly, the results showed that $120 \mu \mathrm{M}$ of Valdecoxib alone (dissolved in $1 \mu \mathrm{L}$ of DMSO) inhibited the growth of MCF7 cells significantly without affecting the normal skin Hacat cells as compared to the controls and solvent control (Table 1 and Figure 1).

At micromolar concentration, the combination of small molecules demonstrated potent growth inhibition activity against cancer cells

The selected small molecules were tested against cancer cell lines alone and in combination for growth inhibitory effects. The results revealed that the combination of $40 \mu \mathrm{M}$ L-Methionine, $40 \mu \mathrm{M}$ Rofecoxib and $40 \mu \mathrm{M}$ Artocarpin, significantly suppressed the growth of more than $90 \%$ PC3 cells $(\mathrm{P}<0.05)$ (Table 1$)$ compared to the control and solvent control. Among other small molecule combinations, the combination of $40 \mu \mathrm{M}$ L-Methionine, $40 \mu \mathrm{M}$ Valdecoxib and $40 \mu \mathrm{M}$ Artocarpin inhibited the growth of approximately 59\% MCF7 cells (Table 1 and Figure 1) while the combination of $30 \mu \mathrm{M}$ Valdecoxib, $30 \mu \mathrm{M}$ Rofecoxib, 30 $\mu \mathrm{M}$ Artocarpin and $30 \mu \mathrm{M}$ L-Methionine inhibited the growth of MCF7 cells by approximately $55 \%$ (Table 1 and Figure 1 ) as compared to the control and solvent control. Other combinations of small molecules showed no significant effects. However, all small molecules and combinations of small molecules did not demonstrate cell survival inhibition against both, cancer cells and normal cells.

At micromolar concentration, the combination of small molecules demonstrated selective cytotoxicity against cancer cells without affecting the viability of normal cells

The cytotoxic activity of different concentrations of small molecules $(30 \mu \mathrm{M}-120 \mu \mathrm{M})$ and peptides $(24 \mu \mathrm{M}-120 \mu \mathrm{M})$ as a single drug or in combination, against HeLa cervical adenocarcinoma cells, MCF-7 breast adenocarcinoma cells, $\mathrm{PC} 3$ prostate adenocarcinoma cells and Hacat normal skin keratinized cells were investigated via LDH cytotoxicity assay. Interestingly, the results showed that the combination of $60 \mu \mathrm{M}$ Valdecoxib and $60 \mu \mathrm{M}$ Artocarpin demonstrated the killing effect of approximately $88 \%$ PC3 cell and 63\% MCF7 cells without affecting the normal Hacat skin cells $(\mathrm{P}<0.05)$ (Table 1 and Figure 2).

Among other drugs, the combination of $60 \mu \mathrm{M}$ L-Methionine and $60 \mu \mathrm{M}$ Artocarpin and the combination of $30 \mu \mathrm{M}$ Valdecoxib, $30 \mu \mathrm{M}$ Rofecoxib, 30 $\mu \mathrm{M}$ Artocarpin 

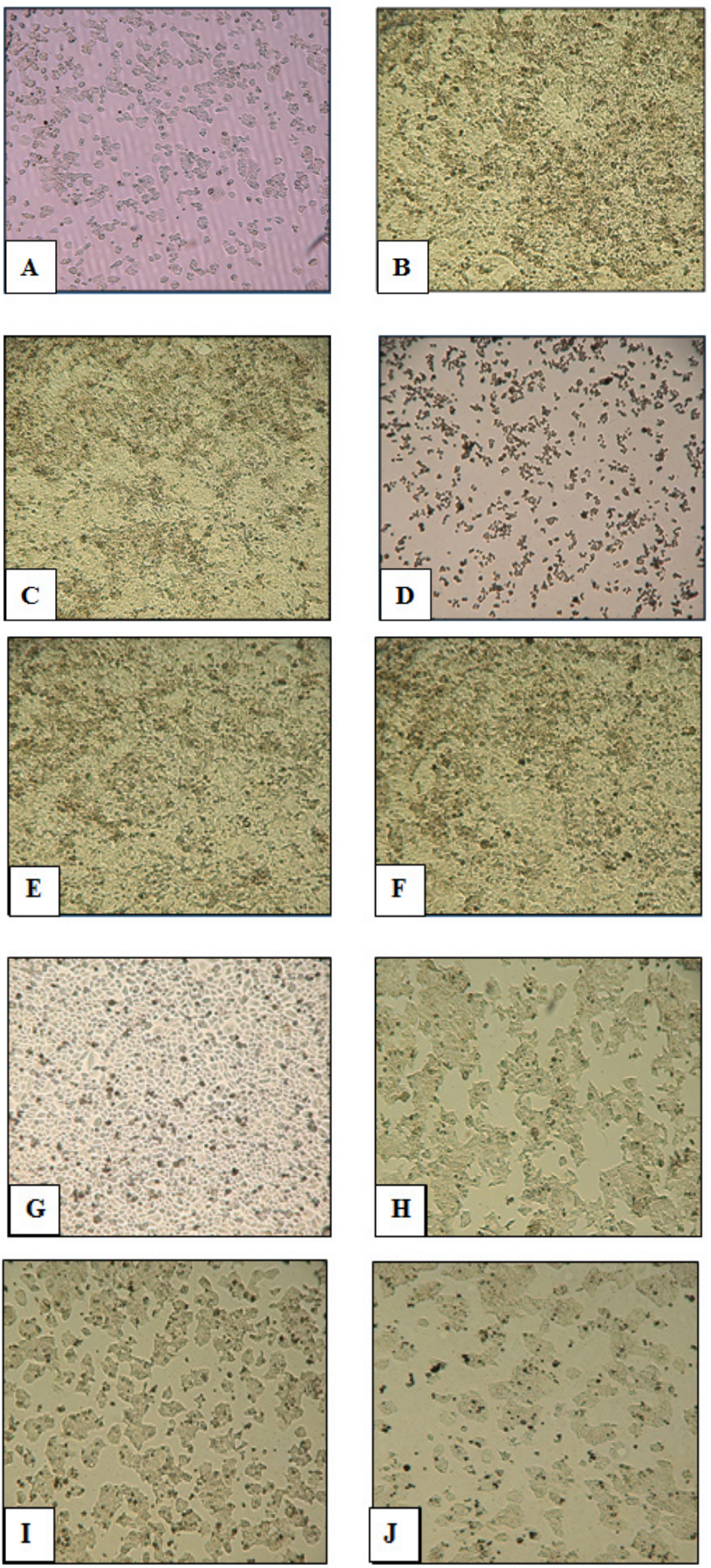

Figure 1. (A-J): Growth inhibition of MCF7 cells treated with small molecules (single and combination). Briefly, cells were cultured onto 96-well plates to approximately 50\% semi-confluent monolayer of cells was achieved. Next, media were removed and cells were incubated with different concentrations of small molecules $(30 \mu \mathrm{M}-120 \mu \mathrm{M})$ and peptides $(24 \mu \mathrm{M}-120 \mu \mathrm{M})$ for $24 \mathrm{~h}$. An initial cell count was performed on the control well to calculate the number of viable cells present in the monolayer of the 50\% semi-confluent well. Once a 100\% confluent monolayer of cells were achieved in the control well, the media was discarded and the cells were trypsinized and enumerated as described in Materials and Methods. The growth inhibition was calculated in this manner: Total cells per $\mathrm{ml}=$ Total cells counted $\mathrm{x}$ [dilution factor/number of counted squares] x 10000 cells per ml. All experiments were conducted at least twice, in duplicate and the results are presented as mean \pm standard error. Representative images of MCF7 cells with and without small molecules (x40) [A: Control at 0h; B: Control at 24h; C: Negative control (Amphicillin); D: Positive control (Cisplatin); E: DMSO solvent; F: Ethanol solvent; G: Distilled water solvent; H: $120 \mu \mathrm{M}$ Valdecoxib; I: $40 \mu \mathrm{M}$ L-Methionine $+40 \mu \mathrm{M}$ Valdecoxib $+40 \mu \mathrm{M}$ Artocarpin; J: 30 $\mu \mathrm{M}$ Valdecoxib $+30 \mu \mathrm{M}$ Rofecoxib $+30 \mu \mathrm{M}$ L-Methionine+30 $\mu \mathrm{M}$ Artocarpin]. 
Table 2. The Cytotoxic Effects of Selected Peptides against Human Cancer and Normal Cells. Cell cytotoxicity assays were performed as described in Materials and Methods. (*indicates $\mathrm{P}<0.05$ using a 2-sample t-test; two-tailed distribution; compared to the relevant control).

\begin{tabular}{|c|c|c|c|c|}
\hline \multirow{2}{*}{$\begin{array}{l}\text { Peptides } \\
\text { (single and } \\
\text { combination) }\end{array}$} & \multicolumn{4}{|c|}{ Cytotoxicity (\%) } \\
\hline & $\mathrm{HeLa}$ & PC3 & MCF7 & Hacat \\
\hline A & $3 \pm 0.65$ & $* 16 \pm 0.41$ & $8 \pm 1.33$ & $26 \pm 1.26$ \\
\hline B & $1 \pm 0.23$ & $12 \pm 1.90$ & $7 \pm 0.72$ & $22 \pm 2.16$ \\
\hline $\mathrm{C}$ & 0 & $* 3 \pm 0.15$ & $* 3 \pm 0.16$ & $22 \pm 0.06$ \\
\hline $\mathrm{D}$ & $5 \pm 1.31$ & $8 \pm 1.73$ & $11 \pm 4.13$ & $24 \pm 0.43$ \\
\hline $\mathrm{E}$ & 0 & $7 \pm 4.66$ & $2 \pm 1.08$ & $18 \pm 3.66$ \\
\hline $\mathrm{A}+\mathrm{B}$ & 0 & $9 \pm 0.87$ & $1 \pm 0.46$ & $24 \pm 2.29$ \\
\hline $\mathrm{A}+\mathrm{C}$ & 0 & $6 \pm 1.68$ & $1 \pm 0.49$ & $18 \pm 3.55$ \\
\hline$A+D$ & 0 & $1 \pm 0.73$ & $1 \pm 0.63$ & $22 \pm 4.10$ \\
\hline $\mathrm{A}+\mathrm{E}$ & 0 & $9 \pm 5.27$ & 0 & $20 \pm 0.80$ \\
\hline $\mathrm{B}+\mathrm{C}$ & 0 & $3 \pm 1.51$ & 0 & $16 \pm 1.19$ \\
\hline$B+D$ & $* 1 \pm 0.04$ & $16 \pm 12.98$ & $* 8 \pm 0.12$ & $37 \pm 7.92$ \\
\hline $\mathrm{B}+\mathrm{E}$ & 0 & $9 \pm 1.90$ & $* 4 \pm 0.30$ & $19 \pm 0.88$ \\
\hline $\mathrm{C}+\mathrm{D}$ & 0 & $6 \pm 2.34$ & $5 \pm 0.82$ & $23 \pm 1.24$ \\
\hline $\mathrm{C}+\mathrm{E}$ & 0 & $5 \pm 1.24$ & $* 2 \pm 0.02$ & $20 \pm 0.20$ \\
\hline $\mathrm{D}+\mathrm{E}$ & 0 & $* 6 \pm 0.17$ & $4 \pm 0.48$ & $22 \pm 0.78$ \\
\hline $\mathrm{A}+\mathrm{B}+\mathrm{C}$ & $2 \pm 0.53$ & $18 \pm 10.53$ & $8 \pm 1.68$ & $27 \pm 8.41$ \\
\hline $\mathrm{A}+\mathrm{B}+\mathrm{D}$ & 0 & $5 \pm 0.47$ & $5 \pm 0.54$ & $21 \pm 1.20$ \\
\hline $\mathrm{A}+\mathrm{B}+\mathrm{E}$ & $1 \pm 0.79$ & $7 \pm 4.90$ & $5 \pm 2.74$ & $20 \pm 0.70$ \\
\hline $\mathrm{A}+\mathrm{C}+\mathrm{D}$ & 0 & $3 \pm 0.95$ & $* 2 \pm 0.14$ & $21 \pm 2.41$ \\
\hline $\mathrm{A}+\mathrm{C}+\mathrm{E}$ & 0 & $* 4 \pm 0.12$ & $1 \pm 1.38$ & $21 \pm 1.07$ \\
\hline $\mathrm{A}+\mathrm{D}+\mathrm{E}$ & $3 \pm 2.43$ & $22 \pm 14.34$ & $10 \pm 3.82$ & $27 \pm 2.48$ \\
\hline $\mathrm{B}+\mathrm{C}+\mathrm{D}$ & $1 \pm 0.22$ & $7 \pm 0.51$ & $6 \pm 0.85$ & $24 \pm 0.23$ \\
\hline $\mathrm{B}+\mathrm{C}+\mathrm{E}$ & $1 \pm 0.49$ & $8 \pm 3.32$ & $6 \pm 0.77$ & $19 \pm 1.27$ \\
\hline $\mathrm{B}+\mathrm{D}+\mathrm{E}$ & 0 & $4 \pm 3.01$ & $4 \pm 2.61$ & $22 \pm 1.39$ \\
\hline $\mathrm{C}+\mathrm{D}+\mathrm{E}$ & $1 \pm 0.52$ & $30 \pm 20.28$ & $5 \pm 2.10$ & $23 \pm 1.81$ \\
\hline $\mathrm{A}+\mathrm{B}+\mathrm{C}+\mathrm{D}$ & 0 & 0 & 0 & 0 \\
\hline $\mathrm{A}+\mathrm{B}+\mathrm{C}+\mathrm{E}$ & 0 & $2 \pm 0.75$ & 0 & 0 \\
\hline $\mathrm{A}+\mathrm{B}+\mathrm{D}+\mathrm{E}$ & $5 \pm 1.99$ & $2 \pm 0.98$ & $8 \pm 8.08$ & 0 \\
\hline $\mathrm{A}+\mathrm{C}+\mathrm{D}+\mathrm{E}$ & 0 & 0 & 0 & 0 \\
\hline $\mathrm{B}+\mathrm{C}+\mathrm{D}+\mathrm{E}$ & 0 & $1 \pm 0.00$ & 0 & $2 \pm 1.60$ \\
\hline $\mathrm{A}+\mathrm{B}+\mathrm{C}+\mathrm{D}+\mathrm{E}$ & 0 & $1 \pm 0.30$ & 0 & 0 \\
\hline \multicolumn{5}{|c|}{ Control } \\
\hline Distilled water & 0 & 0 & 0 & 0 \\
\hline Ampicillin & 0 & 0 & 0 & 0 \\
\hline Cisplatin & $64 \pm 0.42$ & $54 \pm 1.20$ & $60 \pm 0.66$ & $69 \pm 1.51$ \\
\hline
\end{tabular}

and $30 \mu \mathrm{M}$ L-Methionine demonstrated approximately more than $75 \%$ cytotoxicity against PC3 cells whereas the combination of $60 \mu \mathrm{M}$ L-Methionine and $60 \mu \mathrm{M}$ Rofecoxib demonstrated approximately $31 \%$ cytotoxic activity against PC3 cells compared to both, the control and solvent control $(\mathrm{P}<0.05)$ (Table 1 and Figure 2). Cytotoxic activity was not observed in the normal cells incubated with the above-mentioned drug combinations.

Rofecoxib and Artocarpin demonstrated potent cytotoxic activity against cancer cells as a single molecule and in combination with other small molecules

Artocarpin alone demonstrated $100 \%$ cytotoxic activity against PC3 and MCF7 cells and 74\% cytotoxic activity against $\mathrm{HeLa}$ cells $(\mathrm{P}<0.05)$ at the concentration of $120 \mu \mathrm{M}$. Rofecoxib alone, at the concentration of $120 \mu \mathrm{M}$ demonstrated killing effect against approximately $54 \%$ PC3 cells, compared to the control and solvent control (Table 1 and Figure 2). The combination of $60 \mu \mathrm{M}$ Rofecoxib and $60 \mu \mathrm{M}$ Artocarpin destroyed more than $80 \%$ MCF7 and PC3 cells whereas the combination of $60 \mu \mathrm{M}$ Valdecoxib $+60 \mu \mathrm{M}$ Rofecoxib, combination of $40 \mu \mathrm{M}$ L-Methionine $+40 \mu \mathrm{M}$ Valdecoxib $+40 \mu \mathrm{M}$ Rofecoxib and the combination of $40 \mu \mathrm{M}$ Valdecoxib $+40 \mu \mathrm{M}$ Rofecoxib $+40 \mu \mathrm{M}$ Artocarpin demonstrated cytotoxicity against PC3 cells by more than 35\%, compared to the control and solvent control $(\mathrm{P}<0.05)$ (Table 1$)$. However, all small molecules and combinations of small molecules did not demonstrate cell survival inhibition against cancer cells and normal cells.

Peptide sequence 'TFFPETWLWLLK' demonstrated potent cytotoxicity against cancer cells without affecting the normal cells

Among all peptides, either independently or in combination, $120 \mu \mathrm{M}$ of peptide with the sequence 'TFFPETWLWLLK', demonstrated selective cytotoxic activity against cancer cells without distressing the normal cells. $120 \mu \mathrm{M}$ of peptide A, exhibited $16 \%$ cytotoxic activity against PC3 cells without affecting the normal cells as compared to the control (Table 2). However, all peptides and combinations of peptides did not demonstrate growth inhibition and cell survival inhibition against cancer cells and normal cells.

\section{Discussion}

The significant rate of mortality and morbidity of cancer cases (Bray et al., 2018; Ferlay et al., 2015; Parkin et al., 2001) highlights the urgent requirements for new effective anticancer agents. The medicinal properties of natural products remain an important source of therapeutic drugs. Here, we investigated small molecules and peptide sequences which were found in the serum of the salt water crocodile Crocodylus porosus, snake Malayopython reticulatus, Asian water monitor lizard Varanus salvator and tortoise Cuora kamaroma amboinensis. Using prediction tools such as the Machine-Learning-Based Prediction of Anticancer Peptides (MLACP) tool for peptides and literature search via Scifinder, few potential anticancer peptide sequences such as (A) TFFPETWLWLLK, (B) MDPPLLWR, (C)WAFPLK, (D)AFWLLLALHR and (E)LVVPVVVPALFSK as well as a few small molecules such as Valdecoxib, Rofecoxib, Artocarpin and L-Methionine were investigated (Table 3). The above-mentioned peptide sequences and small molecules were tested independently and in combination on cancer cells for growth inhibition and cytotoxic activity. For the present study, HeLa (cervical), MCF7 (breast), PC3 (prostate) cells were used, as cervical, 

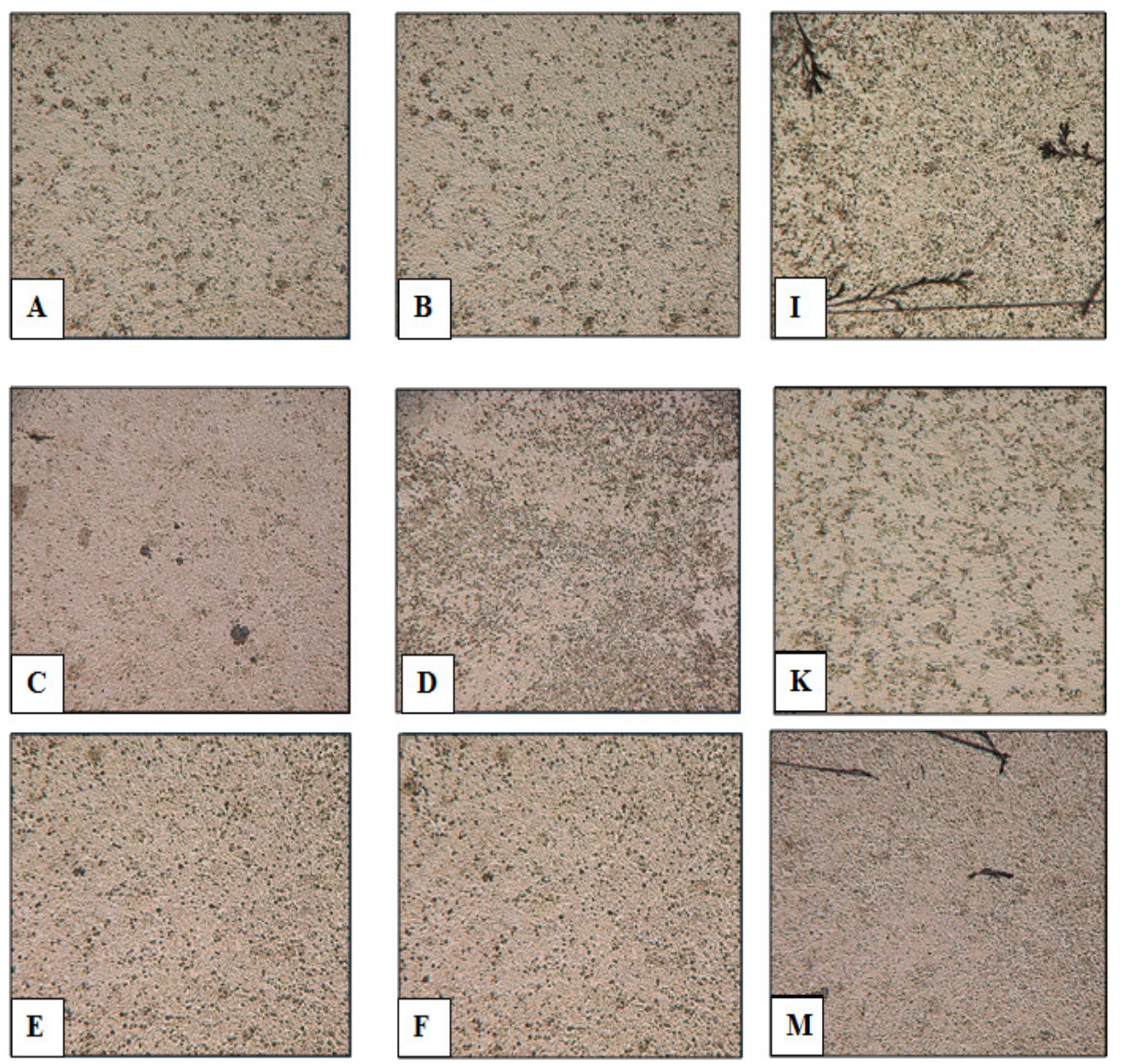

\section{$\mathbf{E}$}

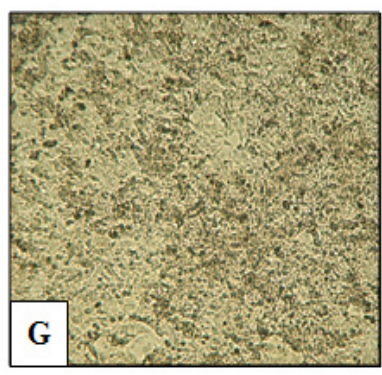

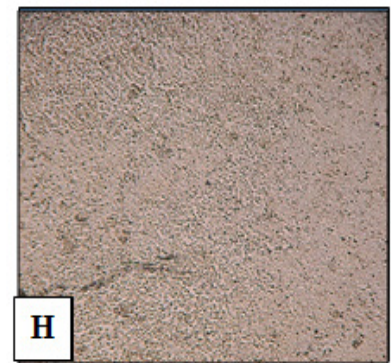

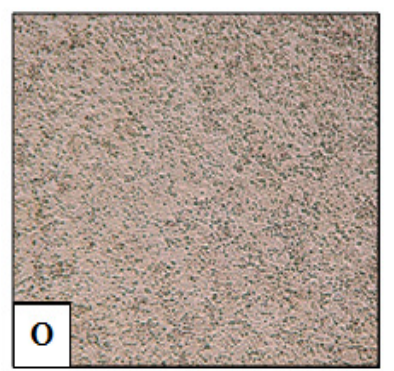

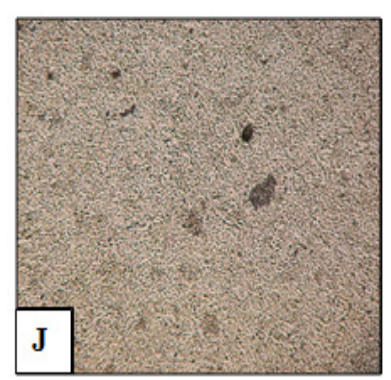
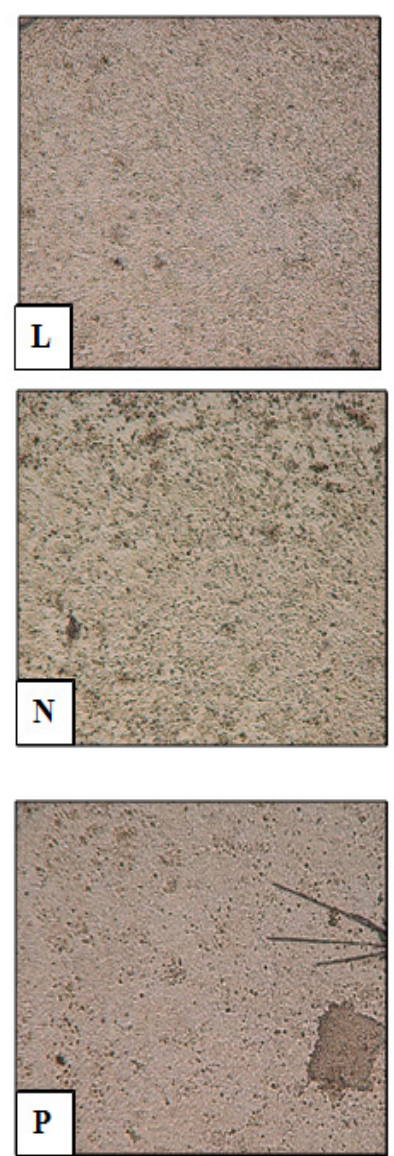

Figure 2 (A-P). Cytotoxic effects of PC3 cells treated with small molecules (single and combination). Briefly, cells were cultivated in 96-well plates until a confluent monolayer is achieved. Next, cells were incubated with different concentrations of small molecules $(30 \mu \mathrm{M}-120 \mu \mathrm{M})$ and peptides $(24 \mu \mathrm{M}-120 \mu \mathrm{M})$ for $24 \mathrm{~h}$ for $24 \mathrm{~h}$ at $37^{\circ} \mathrm{C}$ in a $5 \%$ $\mathrm{CO} 2$ incubator. The negative control wells were treated with media alone, Cisplatin (positive control), Ampicillin (negative control) and DMSO/Ethanol/Distilled water (solvent control). The supernatant from each well were collected and the percentage of cytotoxicity/cell death was determined via Lactate Dehydrogenase (LDH) cytotoxicity kit as described in Materials and Methods. The percentage cell death was calculated using the given formula: (test absorbance value - negative control absorbance value/total LDH release absorbance value - negative control value $\mathrm{x} 100=\%$ cytotoxicity). All experiments were conducted at least twice, in duplicate and the results are demonstrated as mean \pm standard error. Representative images of PC3 cells with and without small molecules (x40) [A: Control at 24h; B: Negative control (Amphicillin); C: Positive control (Cisplatin); D: DMSO solvent; E: Ethanol solvent; F: Distilled water solvent; G: $120 \mu \mathrm{M}$ Rofecoxib; H: $120 \mu \mathrm{M}$ Artocarpin; I: $60 \mu \mathrm{M}$ Rofecoxib+60 $\mu \mathrm{M}$ L-Methionine; J: $60 \mu \mathrm{M}$ Artocarpin $+60 \mu \mathrm{M}$ L-Methionine; K: $60 \mu \mathrm{M}$ Valdecoxib+60 $\mu \mathrm{M}$ Rofecoxib; L: $60 \mu \mathrm{M}$ Valdecoxib+60 $\mu \mathrm{M}$ Arto-

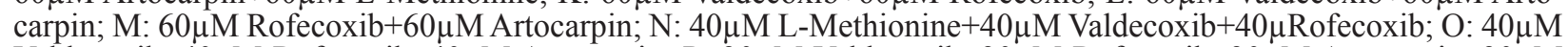
Valdecoxib $+40 \mu \mathrm{M}$ Rofecoxib $+40 \mu \mathrm{M}$ Artocarpin; P: $30 \mu \mathrm{M}$ Valdecoxib $+30 \mu \mathrm{M}$ Rofecoxib $+30 \mu \mathrm{M}$ Artocarpin $+30 \mu \mathrm{M}$ L-Methionine].

breast, and prostate cancer represents a significant burden on human health.

$120 \mu \mathrm{M}$ of Valdecoxib alone exhibited significant growth inhibition activity against MCF7 cells without affecting the normal skin Hacat cells (Table 1). This was consistent with the findings which showed the ability of Valdecoxib, a type isoxazole (Chikkula and Raja, 2017) with COX-2 inhibitor activity, was previously used to treat inflammation, osteoarthritis (Genç et al., 2017) and even cancer (Atukorala and Hunter, 2013; Daniels et al., 2005; Kivitz et al., 2002). COX-2 is an enzyme which was found to be highly expressed in certain types of cancer such as colorectal cancer (Genç et al., 2017; Atukorala and Hunter, 2013; Daniels et al., 2005; Kivitz et al., 2002; Wang and DuBois, 2010). However, although the normal cells used in this study was not affected by Valdecoxib, previous 
Table 3. Source of Selected Small Molecules and Peptide Sequences

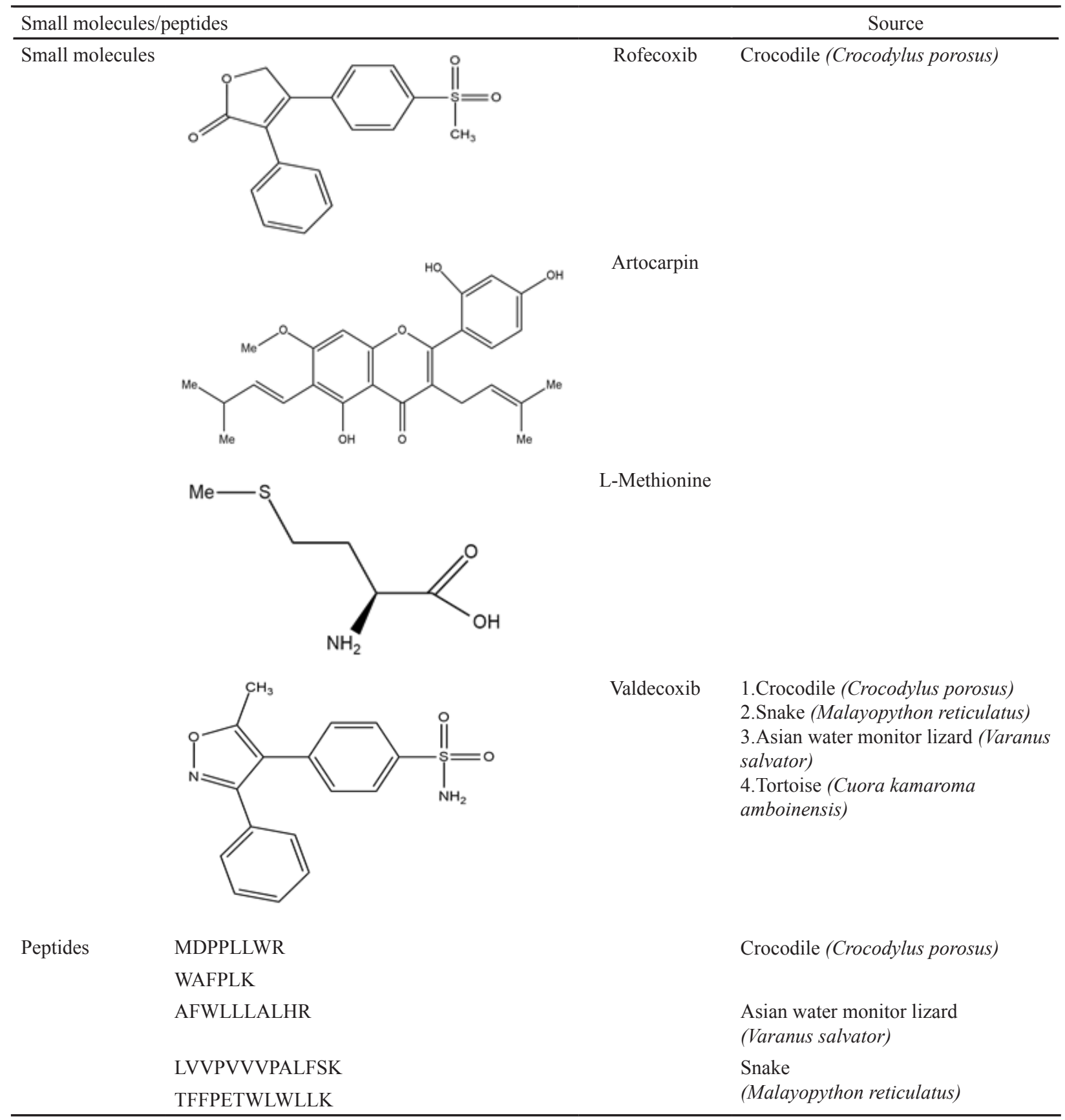

findings demonstrated the presence of side effects such as cardiovascular complications in Valdecoxib treated patients, which resulted in the withdrawal of valdecoxib from the market in year 2005 by the FDA agency of the United States Department of Health and Human Services and the European Medicines Agency (EMEA) (Genç et al., 2017; Atukorala and Hunter, 2013). At micromolar concentration, the combination of small molecules also demonstrated potent growth inhibition activity and cytotoxic activity against cancer cells. Valdecoxib and Rofecoxib are types of COX-2 inhibitors which could possibly inhibit cancer cell growth via the inhibition of COX-2 expression. However, detailed studies are required to confirm this hypothesis. On the other hand, L-Methionine had demonstrated growth inhibition activity against BXPC-3 (mutated p53) and HPAC (wild-type p53) pancreatic cancer cells via causing cell cycle arrest and triggering apoptosis (Benavides et al., 2014). Older studies have demonstrated the ability of Artocarpin in hindering cell growth and initiating apoptosis mechanism in human colon cells (Sun et al., 2017). These studies further support our findings which showed the presence of anticancer activity against cancer cells treated with these small molecules in combination.

Among other peptides, $120 \mu \mathrm{M}$ of peptide with the sequence 'TFFPETWLWLLK', which were found in the serum of snake, Malayopython reticulatus demonstrated selective cytotoxic activity against prostate cancer cells and not against normal cells. However, all peptides and combinations of peptides did not demonstrate growth inhibition and cell survival inhibition against cancer cells and normal cells. These findings were constant with another study which demonstrated the presence of cytotoxic proteins from the serum of the African rock 
Table 4. Order of Small Molecules/Peptides Tested against Cancer Cells and Reported Activity

\begin{tabular}{|c|c|c|}
\hline \multicolumn{3}{|c|}{ Small molecules } \\
\hline \multirow[t]{2}{*}{ L-Methionine } & \multicolumn{2}{|c|}{ Combinations tested in this study $(120 \mu \mathrm{M})$} \\
\hline & \multicolumn{2}{|l|}{ 1. L-Methionine } \\
\hline \multirow[t]{2}{*}{ Valdecoxib } & \multicolumn{2}{|l|}{ 2. Valdecoxib } \\
\hline & \multicolumn{2}{|l|}{ 3. Rofecoxib } \\
\hline Rofecoxib & \multicolumn{2}{|l|}{ 4. Artocarpin } \\
\hline \multirow[t]{15}{*}{ Artocarpin } & \multicolumn{2}{|c|}{$60 \mu \mathrm{M}+60 \mu \mathrm{M}$} \\
\hline & \multicolumn{2}{|c|}{ 5. L-Methionine + Valdecoxib } \\
\hline & \multicolumn{2}{|c|}{ 6. L-Methionine + Rofecoxib } \\
\hline & \multicolumn{2}{|c|}{ 7. L-Methionine + Artocarpin } \\
\hline & \multicolumn{2}{|c|}{ 8. Valdecoxib + Rofecoxib } \\
\hline & \multicolumn{2}{|c|}{ 9. Valdecoxib + Artocarpin } \\
\hline & \multicolumn{2}{|c|}{ 10. Rofecoxib + Artocarpin } \\
\hline & \multicolumn{2}{|c|}{$40 \mu \mathrm{M}+40 \mu \mathrm{M}+40 \mu \mathrm{M}$} \\
\hline & \multicolumn{2}{|c|}{ 11. L-Methionine + Valdecoxib + Rofecoxib } \\
\hline & \multicolumn{2}{|c|}{ 12. L-Methionine + Valdecoxib + Artocarpin } \\
\hline & \multicolumn{2}{|c|}{ 15.L-Methionine + Rofecoxib + Artocarpin } \\
\hline & \multicolumn{2}{|c|}{ 16. Valdecoxib + Rofecoxib + Artocarpin } \\
\hline & \multicolumn{2}{|c|}{$30 \mu \mathrm{M}+30 \mu \mathrm{M}+30 \mu \mathrm{M}+30 \mu \mathrm{M}$} \\
\hline & \multicolumn{2}{|c|}{$\begin{array}{l}\text { 17. Valdecoxib }+ \text { Rofecoxib }+ \text { Artocarpin }+ \\
\text { L-Methionine }\end{array}$} \\
\hline & \multicolumn{2}{|c|}{ Peptides } \\
\hline Symbol & Peptide sequence & $\begin{array}{l}\text { Combinations tested in this } \\
\text { study }(120 \mu \mathrm{M})\end{array}$ \\
\hline A & TFFPETWLWLLK & 1.A/ B/ C/ D/ E \\
\hline $\mathrm{B}$ & MDPPLLWR & $60 \mu \mathrm{M}+60 \mu \mathrm{M}$ \\
\hline $\mathrm{C}$ & WAFPLK & 2. $\mathrm{A}+\mathrm{B} / \mathrm{A}+\mathrm{C} / \mathrm{A}+\mathrm{D} / \mathrm{A}+\mathrm{E} / \mathrm{B}+\mathrm{C} /$ \\
\hline $\mathrm{D}$ & AFWLLLALHR & $\mathrm{B}+\mathrm{D} / \mathrm{B}+\mathrm{E} / \mathrm{C}+\mathrm{D} / \mathrm{C}+\mathrm{E} / \mathrm{D}+\mathrm{E}$ \\
\hline \multirow[t]{4}{*}{$\mathrm{E}$} & LVVPV- & \\
\hline & VVPALFSK & $\begin{array}{l}\quad 40 \mu \mathrm{M}+40 \mu \mathrm{M}+40 \mu \mathrm{M} \\
\text { 3. } \mathrm{A}+\mathrm{B}+\mathrm{C} / \mathrm{A}+\mathrm{B}+\mathrm{D} / \mathrm{A}+\mathrm{B}+\mathrm{E} / \\
\mathrm{A}+\mathrm{C}+\mathrm{D} / \mathrm{A}+\mathrm{C}+\mathrm{E} / \mathrm{A}+\mathrm{D}+\mathrm{E} / \\
\mathrm{B}+\mathrm{C}+\mathrm{D} / \mathrm{B}+\mathrm{C}+\mathrm{E} / \mathrm{B}+\mathrm{D}+\mathrm{E} / \\
\mathrm{C}+\mathrm{D}+\mathrm{E}\end{array}$ \\
\hline & & $\begin{array}{l}30 \mu \mathrm{M}+30 \mu \mathrm{M}+30 \mu \mathrm{M}+30 \mu \mathrm{M} \\
4 . \mathrm{A}+\mathrm{B}+\mathrm{C}+\mathrm{D} / \mathrm{A}+\mathrm{B}+\mathrm{C}+\mathrm{E} / \\
\mathrm{A}+\mathrm{B}+\mathrm{D}+\mathrm{E} / \mathrm{A}+\mathrm{C}+\mathrm{D}+\mathrm{E} / \\
\mathrm{B}+\mathrm{C}+\mathrm{D}+\mathrm{E}\end{array}$ \\
\hline & & $\begin{array}{c}24 \mu \mathrm{M}+24 \mu \mathrm{M}+24 \mu \mathrm{M}+24 \mu \mathrm{M} \\
+24 \mu \mathrm{M} \\
\text { 5. } \mathrm{A}+\mathrm{B}+\mathrm{C}+\mathrm{D}+\mathrm{E}\end{array}$ \\
\hline
\end{tabular}

python, Python sebae. The identified peptides/proteins exerted significant cytotoxicity and inhibited the growth of human squamous cell carcinoma cells, in vitro and in vivo (Donnini et al., 2011). These findings show that animals living in polluted environments possess molecules which have potential anticancer activities.

In Conclusion, we showed that the small molecules and peptides from the serum of animals living in polluted environments such as the salt water crocodile Crocodylus porosus, snake Malayopython reticulatus, Asian water monitor lizard Varanus salvator and tortoise Cuora kamaroma amboinensis possess potential anticancer molecules which works as an effective anticancer agent when used in combination or independently. As a result, these molecules could serve as potential drug leads but further research is needed to realize these expectations. These findings strengthen the fact that animals inhabiting polluted milieus is definitely an area which needs to be exploited for potential pharmaceutical anticancer drugs which may result in the discovery and identification of novel anticancer molecule(s) and/or understanding of cancer resistance mechanisms. This hypothesis-driven research is timely and topical and it is worth investigating an untapped source of pharmaceutical drug-leads that will likely lead to the identification of novel antitumor compound(s).

\section{Acknowledgements}

The work in this paper was supported, in part, by the Open Access Program from the American University of Sharjah. This paper represents the opinions of the author(s) and does not mean to represent the position or opinions of the American University of Sharjah. Authors are grateful to Sunway University, Malaysia to provide technical support.

\section{Declarations}

Ethics Approval and Consent to Participate: This article does not contain any studies with human participants.

\section{Consent for Publication \\ Not applicable.}

\section{Funding}

The work is supported by the American University of Sharjah.

\section{Conflict of interest}

The authors declare no conflict of interest, financial or otherwise.

\section{Authors' contributions}

RS and NAK conceived the project. SJ designed and conducted experiments under the supervision of RS. SJ wrote the first draft of the manuscript. RS and NAK All authors approved the final manuscript.

\section{References}

Atukorala I, Hunter DJ (2013). Valdecoxib: the rise and fall of a COX-2 inhibitor. Expert Opin Pharmacother, 14, 1077-86.

Benavides MA, Bosland MC, da Silva CP et al, (2014). L-Methionine inhibits growth of human pancreatic cancer cells. Anti-Cancer Drugs, 25, 200.

Bray F, Ferlay J, Soerjomataram I, et al (2018). Global cancer statistics 2018: GLOBOCAN estimates of incidence and mortality worldwide for 36 cancers in 185 countries. $C A$ Cancer J Clin, 68, 394-424.

Chandna S, Dwarakanath BS, Seth RK, et al (2004). Radiation responses of $\mathrm{Sf} 9$, a highly radioresistant lepidopteran insect cell line. Int $J$ Radiation Biol, 80, 301-15.

Chikkula KV, Raja S (2017). Isoxazole-a potent pharmacophore. Int J Phar Pharmaceut Sci, 9, 13-24.

Daniels SE, Torri S, Desjardins PJ (2005). Valdecoxib for treatment of primary dysmenorrhea. J Gen Int Med, $\mathbf{2 0}$, 62-67.

Donnini S, Finetti F, Francese S, et al, (2011). A novel protein from the serum of Python sebae, structurally homologous with type- $\gamma$ phospholipase A2 inhibitor, displays antitumour Asian Pacific Journal of Cancer Prevention, Vol 22 
activity. Biochem J, 440, 251-62.

Ehrhardt H, Pannert L, Pfeiffer S, et al (2013). Enhanced antitumour effects of Vinca alkaloids given separately from cytostatic therapies. Br J Pharmacol, 168, 1558-69.

Ferlay J, Soerjomataram I, Dikshit R, et al (2015). Cancer incidence and mortality worldwide: sources, methods and major patterns in GLOBOCAN 2012. Int J Cancer, 136, 359-86.

Genç AI, Gok S, Banerjee S, et al (2017). Valdecoxib recovers the lipid composition, order and dynamics in colon cancer cell lines independent of COX-2 expression: an ATR-FTIR spectroscopy study. Appl Spectroscopy, 71, 105-17.

Jeyamogan S, Khan NA, Siddiqui R (2017). Animals living in polluted environments are a potential source of anti-tumor molecule (s). Cancer Chemother Pharmacol, 80, 919-24.

Jeyamogan S, Khan NA, Kuppusamy S, et al, (2019). Sera/organ lysates of selected animals living in polluted environments exhibit cytotoxicity against cancer cell lines. Anti-Cancer Agents Med Chem, 19, 2251-68.

Kampan NC, Madondo MT, McNally OM, et al, (2015). Paclitaxel and itsevolving role in the management of ovarian cancer. Biomed Res Int, 2015, e413076.

Kang K, Oh SH, Yun JH, et al (2011). A novel Topoisomerase inhibitor, Daurinol, suppresses growth of HCT116 cells with low Hematological toxicity compared to Etoposide. Neoplasia, 13, 1043-57.

Kivitz A, Eisen G, Zhao WW, et al (2002). Randomized placebocontrolled trial comparing efficacy and safety of valdecoxib with naproxen in patients with osteoarthritis. J Family Practice, 51, 530-7.

Lehner AF, Rumbeiha W, Shlosberg A, et al (2013). Diagnostic analysis of veterinary dried blood spots for toxic heavy metals exposure. J Analyt Toxicol, 37, 406-22.

Ma X, Wang Z (2009). Anticancer drug discovery in the future: an evolutionary perspective. Drug Discovery Today, 14, 1136-42.

Parkin DM, Bray F, Ferlay J, et al (2001). Estimating the world cancer burden: Globocan 2000. Int J Cancer, 94, 153-6.

Siddiqui R, Jeyamogan S, Ali SM, et al (2017). Crocodiles and alligators: Antiamoebic and antitumor compounds of crocodiles. Exp Parasitol, 183, 194-200.

Siegel RL, Miller KD, Jemal A (2020). Cancer statistics, 2020. CA Cancer J Clin, 70, 7-30.

Sun G, Zheng Z, Lee MH, et al (2017). Chemoprevention of colorectal cancer by artocarpin, a dietary phytochemical from Artocarpus heterophyllus. J Agricul Food Chem, 65, 3474-80.

Sykes JM, Trupkiewicz JG (2006). Reptile neoplasia at the Philadelphia zoological garden, 1901-2002. J Zoo Wildlife Med, 37, 11-9.

Tellez M, Merchant M (2015). Biomonitoring heavy metal pollution using an aquatic apex predator, the American alligator, and its parasites. PLoS One, 10, e 0142522.

Wang D, DuBois RN (2010). The role of COX-2 in intestinal inflammation and colorectal cancer. Oncogene, 29, 781.

Xu Q, Fang S, Wang Z, et al (2006). Heavy metal distribution in tissues and eggs of Chinese alligator (Alligator sinensis). Arch Environ Contam Toxicol, 50, 580-6.

This work is licensed under a Creative Commons AttributionNon Commercial 4.0 International License. 